NBER WORKING PAPER SERIES

\title{
ALTERNATIVE METHODS OF PRICE \\ INDEXING SOCIAL SECURITY: \\ IMPLICATIONS FOR BENEFITS AND SYSTEM FINANCING
}

\author{
Andrew G. Biggs \\ Jeffrey R. Brown \\ Glenn Springstead \\ Working Paper 11406 \\ http://www.nber.org/papers/w11406
}

\author{
NATIONAL BUREAU OF ECONOMIC RESEARCH \\ 1050 Massachusetts Avenue \\ Cambridge, MA 02138 \\ June 2005
}

We thank Preston Jacobs and Joni Lavery for their assistance with earlier drafts of this paper. We also thank Ed DeMarco, Eric Engen, Dean Leimer, Joyce Manchester, David Pattison, Paul Van de Water and Pat Vinkenes for helpful comments and discussions. All ideas expressed herein are those of the authors, and not of the Social Security Administration. The views expressed herein are those of the author(s) and do not necessarily reflect the views of the National Bureau of Economic Research.

(C2005 by Andrew G. Biggs, Jeffrey R. Brown, Glenn Springstead. All rights reserved. Short sections of text, not to exceed two paragraphs, may be quoted without explicit permission provided that full credit, including () notice, is given to the source. 
Alternative Methods of Price Indexing Social Security: Implications for Benefits and System Financing

Andrew G. Biggs, Jeffrey R. Brown, Glenn Springstead

NBER Working Paper No. 11406

June 2005

JEL No. H55, J14

\title{
$\underline{\text { ABSTRACT }}$
}

This paper explains four methods of "price indexing" initial Social Security retirement benefits, and discusses the effect of each method on the fiscal sustainability of Social Security, benefit levels and replacement rates, redistribution, and sensitivity of system finances to demographic and economic shocks. Of these methods, PIA Factor Indexing would generate the largest cost savings while reducing benefit growth at approximately an equal rate for all income levels. Methods that index the AIME, the formula "bend points," or both, would reduce benefit growth at a slower rate and would have different effects on benefit distribution and system sustainability.

\author{
Andrew G. Biggs \\ Social Security Administration \\ 500 E Street SW \\ Washington, DC 20254 \\ andrew.biggs@ssa.gov \\ Jeffrey R. Brown \\ 340 Wohlers Hall, MC-706 \\ University of Illinois at Urbana-Champaign \\ Champaign, IL 61822 \\ and NBER \\ brownjr@uiuc.edu \\ Glenn Springstead \\ Social Security Administration \\ 500 E Street SW \\ Washington, DC 20254 \\ glenn.sprinstead@ssa.gov
}




\section{Introduction}

An original intent behind Social Security's Old Age and Survivors insurance program was, according to President Franklin Roosevelt, to provide "some measure of protection for the average worker and his family against the loss of a job and against poverty-ridden old age." ${ }^{1}$ Enacted during the depths of the Great Depression, Social Security was a response to economic and social changes that had left many older Americans without sufficient resources to keep out of poverty in old age. As the program has evolved over the following seven decades, the benefit calculation has been modified numerous times, often in pursuit of multiple social policy objectives.

There are at least three policy goals embedded in the current benefit formula, which has been in place since the late 1970s. First, the benefit formula is structured to maintain a relatively constant ratio of retirement benefits to average lifetime, known as a "replacement rate," across successive cohorts of retirees. ${ }^{2}$ For example, a medium wage retiree today receives benefits equal to roughly 40 percent of his earnings, which is quite similar to the replacement rate projected for the typical retiree thirty years hence. ${ }^{3}$ This replacement rate approach is achieved by indexing the benefit formula to wage growth. Thus, when average wages in the economy grow over time, initial benefit levels available to new retirees grow roughly in tandem.

A second goal of the system has been to maintain a progressive benefit structure, such that lower earning recipients receive relatively more benefits as a percentage of their lifetime

\footnotetext{
${ }^{1}$ President Roosevelt's Message to Congress, Transmitting The Report Of The Committee On Economic Security, January 17,1935

${ }^{2}$ It is worth noting that the replacement rate at the normal retirement age has fluctuated considerably over the years, fluctuating between 15 percent and 30 percent from 1940 through 1969, before rapidly climbing above 40 percent by 1975 . Over the past 30 years, the replacement rate has fluctuated between 38.7 percent and 51.7 percent. For the full history, see Table VI.F10 of the 2005 Trustees Report, available at http://www.ssa.gov/OACT/TR/TR05/lr6F10$2 / \mathrm{html}$. For an alternative perspective on the comparison between past planned and current replacement rates, please see Robert J. Myers (1993), Social Security, Appendix, 3-5, pp. 361-365.

32004 OASDI Trustees Report Table VI:F11. The medium scaled workers is projected to receive 42.5 percent of income in 2004 and 41 percent in 2035 given they retire at the normal retirement age.
} 
taxable earnings than do higher earning individuals. In pursuit of this goal, a non-linear benefit formula has been used to provide a higher replacement rate for individuals with lower average earnings over their lifetimes. Of course, a spate of recent academic papers have called into question the degree of income progressivity that the current Social Security system actually achieves in practice (e.g., Coronado, Fullerton and Glass 2000; Gustman \& Steinmeier 2001; Liebman 2002; Steuerle, Carasso, and Cohen 2004). These papers highlight the shortcomings of analyzing progressivity based solely on a comparison of the annual replacement rate based on individual earnings. Nonetheless, the non-linear benefit formula is one relevant input into the overall progressivity of the system.

A third goal of Social Security's benefit structure is to reduce the OASDI system's sensitivity to the unpredictable but inevitable deviations from economic and demographic projections. Because benefit levels and tax revenues are both linked to average wage growth, unanticipated changes to overall wage levels have a smaller effect on the net fiscal balance of the system than would be the case if these linkages did not exist.

Of course, policy decisions about the desired level and distribution of benefits and replacement rates have fiscal implications for the Social Security system, the overall federal budget, and the U.S. macro economy. It is now widely understood that the existing combination of benefit levels and tax rates is not fiscally sustainable and that some combination of benefit and tax changes is required to balance Social Security's finances over the long run. In response to large forecasted deficits, there have been numerous proposals in recent years to change the way that benefits are calculated. One idea that has received a tremendous amount of public attention, due largely to its prominence in the 2001 report of the President's Commission to Strengthen 
Social Security, ${ }^{4}$ is to change the way that initial benefits are calculated so that real benefit levels, rather than replacement rates, are relatively constant over time. This proposal is popularly referred to as "price indexing," though the Commission adopted just one of several potential variants. While price indexing future benefits is only one of many possible approaches to help restore long-term fiscal balance to Social Security, its prominence in the recent debate, and some misunderstanding of how it functions, motivates this paper.

At the heart of the debate over what the benefit formula should look like in future years are three questions. First, should benefits be designed to furnish a constant real level of purchasing power, or should they furnish a level of purchasing power relative to average wages at the time? Second, how will any changes to the benefit formula affect the extent of redistribution across individuals with different lifetime earnings? Third, given the demographic changes that are leading to projected program expenditures rising faster than tax revenues and faster than GDP, how can these prior two policy questions be answered while also securing longterm solvency of the program?

The primary purpose of this paper is to examine the effect of price indexing on benefit levels, replacement rates and fiscal sustainability. To do so, it is important to distinguish between several alternative definitions of what it means to "price index" initial Social Security benefits. In particular, we distinguish four alternative approaches to price indexing benefits: 1) Indexing lifetime earnings (AIME Indexing); 2) Indexing the formula bend points (Bend Point Indexing); 3) Combining AIME and Bend Point Indexing; and 4) Indexing the PIA factors (PIA Factor Indexing). We estimate the effects of each of these four approaches on benefit levels and replacement rates over time and across the AIME distribution. We report projections from the Social Security Administration's Office of the Chief Actuary showing each approach's impact on

\footnotetext{
${ }^{4}$ Final Report of the President's Commission to Strengthen Social Security, December 2001
} 
the program's long-term actuarial deficit. We also discuss some of the trade-offs for policymakers that are involved in each of the approaches.

This paper proceeds as follows. In the first section, we briefly explain how retirement benefits are calculated under the present law, which is commonly referred to as a "wage indexed" system. In section two, we explain why, as a result of demographic changes, the existing system is not fiscally sustainable without a reduction in scheduled benefits and/or an increase in revenue. The four alternative methods of "price indexing" benefits are explained in section three. Sections four, five, and six explore the effect of these alternative forms of price indexing on average benefit levels, redistribution, and system financing respectively. ${ }^{5}$ Section seven summarizes the policy trade-offs and implications for each price indexing approach.

Section eight concludes.

\section{How Retirement Benefits are Calculated Under Present Law}

Under present law, an individual's Social Security retirement benefit is a non-linear function of that worker's average lifetime earnings, with the earnings in each year adjusted for average wage growth in the economy. The non-linearity of the benefit formula is what gives rise to redistribution across lifetime earnings groups.

Calculation of the benefit begins by computing a worker's Average Indexed Monthly Earnings (AIME). Throughout an individual's working life, the Social Security Administration tracks his or her covered earnings in that year. To calculate the AIME, nominal earnings for the

\footnotetext{
${ }^{5}$ A note on the data and methodology used in this paper: Figures reflecting the change in benefits from the four price indexing options referenced in the text and shown in the tables at the end of this document were computed by the authors and are based on assumptions in the 2004 Report of the OASDI Trustees, the most recent report that was available when the main data for this paper was compiled. Figures reflecting the solvency impact of the four options comes from the SSA's Office of the Chief Actuary and was based on the 1999 Trustees Report, which was the TR used by the SSA Actuaries when projections for the four price indexing methods were last made. Finally, general comments on the state of OASDI program financing reflect the most recent data from the 2005 OASDI Trustees Report, released in March of this year.
} 
individual in each calendar year are multiplied by Social Securities' Average Wage Index (AWI). The wage data tabulated by SSA are based on wages reported on W-2's. ${ }^{6}$ This wageindexing procedure expresses past earnings in dollar amounts equivalent to earnings at the time a beneficiary reaches 60 years of age. Earnings after age 60 are not indexed. For example, if a worker retiring at age 62 in 2004 earned the national average wage of $\$ 5,572$ in 1968, those wages indexed to be worth $\$ 33,252$, the average wage in 2002 (when the beneficiary turned 60 ) and are credited toward the worker's benefits in $2004{ }^{7}$

After each year's wages are converted, the top thirty-five years of indexed earnings are averaged by totaling them and dividing by 420 (the number of months in 35 years). These highest 35 earnings-years can include including non-indexed years after age 60 as well as zeros, if there are fewer than 35 years of positive earnings. The resulting number, which is meant to be representative of average lifetime earnings, is that worker's AIME.

The second step is to feed the AIME through a non-linear formula to calculate the "Primary Insurance Amount," or PIA. In 2005, the formula for calculating the PIA is:

$$
\begin{aligned}
\text { PIA }= & 0.90 * \min [\text { AIME, \$627] } \\
& +0.32 * \max [0,(\min [\text { AIME, } \$ 3,779]-\$ 627)] \\
& +0.15 * \max [0, \text { AIME }-\$ 3,779]
\end{aligned}
$$

This formula can be seen graphically in figure 1.

As an example, if a worker has an AIME of $\$ 1,000$, then his PIA would be $\$ 684$ (\$627 multiplied by 90 percent, plus $\$ 373$ by 32 percent). The two dollar-values where the slope changes ( $\$ 627$ and $\$ 3,779$ ) are referred to as the "bend point dollar amounts," or just "bend points." The 90,32 and 15 percent replacement rates are referred to as the "bend point factors,"

\footnotetext{
${ }^{6}$ More details of the calculation of the AWI are available at http://www.socialsecurity.gov/OACT/COLA/AWI.html ${ }^{7}$ See Examples of Benefit Calculations for Workers Attaining Age 62 in 2004; Social Security Office of the Actuary; available www.ssa.gov/OACT/ProgData/nominalEarn.html. (\$6,000 times the 1968 indexing factor of 5.96797)
} 
although to distinguish these components of the formula from the bend point dollar amounts we will refer to them throughout this paper as the "PIA factors".

If an individual retires at their Full Retirement Age (FRA), their basic monthly retirement benefit is equal to the PIA. ${ }^{8}$ In the event that one claims benefits prior to the FRA, their benefit is actuarially reduced. For example, an individual claiming at age 62 in the year 2005 would receive benefits equal to 75 percent of the PIA. Similarly, individuals who delay claiming beyond the FRA receive a delayed retirement credit that increases their benefit payment. ${ }^{9}$ For example, if today's 62 year old delayed claiming until age 70, he or she would receive a benefit equal to 132 percent of their PIA. ${ }^{10}$

The bend point amounts in the Social Security retirement formula, equal to $\$ 627$ and $\$ 3,779$ in 2005 , increase annually based on average wage growth. ${ }^{11}$ For example, in 2004 , the relevant bend points were $\$ 612$ and $\$ 3,689$. Once an individual has reached age 62 or become entitled to disability benefits, their future benefit is adjusted annually to reflect changes in the Consumer Price Index (CPI).

The net result of this AIME-PIA calculation and the annual indexation of the bend points is that the initial benefit level is indexed to wage growth, whereas retirement benefits after age 62 are linked to inflation. Because wages typically rise faster than prices, real benefit levels tend to increase from one cohort to the next. Because the formula for calculating benefits adjusts both

\footnotetext{
${ }^{8}$ For the cohort turning age 62 in the year 2005, the FRA is 66 years. In the year 2017, the FRA is scheduled to begin rising again, reaching age 67 in year 2022. The Full Retirement Age is also commonly referred to as the Normal Retirement Age.

${ }^{9}$ The actuarial adjustment for early retirement is known as the "early retirement reduction" while the adjustment for later retirement is known as the "delayed retirement credit."

${ }^{10}$ Assumes someone turning 62 in 2005, with an FRA of 66, who waited four years beyond the FRA to file for benefits, and receiving an 8 percent DRC for each year of delayed retirement.

${ }^{11}$ Technically, there is a two year lag between the year the PIA is computed (age 62 for retired workers) and last year of earnings that are available (age 60) to be used for indexing purposes. To implement the bend point indexing, the first bend point from 1979 (\$180) is multiplied by the ratio of the average earnings in the year the person turns age 60 to the average wage in 1977.
} 
earnings and the bend points to reflect average wage increases, Social Security benefits rise over time so that retirement benefits continue to equal a roughly constant fraction of pre-retirement income, even while standards of living are rising.

Indeed, one implication of the formula is that real benefits will increase even for individuals whose wages do not keep pace with average wage growth. Assuming wage growth exceeds price growth, if two individuals of different cohorts have identical, constant real lifetime earnings, the individual in the later cohort would receive higher benefits under the current benefit formula than the individual in the earlier cohort. For instance, an individual who earned $\$ 25,000$ annually (in 2004 dollars) and retires in 2004 would receive a monthly benefit of $\$ 1,163$. An individual who earned $\$ 25,000$ annually (in 2004 dollars) and retires in 2050 would receive a monthly benefit of $\$ 1,407$. This increase occurs because the bend points are increased annually along with wage growth, so that a greater share of a given level of earnings would be covered under the more generous 90 and 32 percent PIA factors. Of course, a \$25,000 earner in the future, assuming average real wage growth, would be lower down the earnings distribution in the future than they are today. If a policy goal is to redistribute from high AIME to low AIME individuals within the same cohort, then the $\$ 25,000$ earner in the future should benefit more from the progressive benefit formula than a similar worker today.

\section{The Fiscal Sustainability of the Existing Benefit and Tax Structure}

According to the intermediate assumptions in the 2005 Social Security OASDI Trustees Report, if no changes are made, in 2017 the Social Security program will begin paying out more in benefits than it takes in from taxes. As seen in Figure 2, the Trustees project that the annual cash flow deficits that start in 2017 would grow every year. 
According to the 2005 Social Security OASDI Trustees' Report, if no changes are made, in 2017 the Social Security program will begin paying out more in benefits than it takes in from taxes. As seen in figure 2, the annual cash flow deficits that start in 2017 grow every year. For perspective, just a decade later in the year 2027, the annual cash flow deficit from Social Security will exceed $\$ 200$ billion (in 2005 dollars).

During the period from 2017 to 2041, Social Security has the legal ability to pay full benefits by relying on the interest and principal in the Social Security trust funds. Of course, from the perspective of the overall federal budget, the money to redeem the trust fund bonds for Social Security must come from increased taxes, reduced government spending, or higher levels of borrowing from the public. When trust fund assets are exhausted in the year 2041, the dedicated tax revenues would be able to finance only 74 percent of scheduled benefits.

Over the next 75 years, under the Trustees intermediate assumptions, the present value of the Social Security shortfalls, net of the surpluses run for the next 12 years, is $\$ 4.0$ trillion, or 1.92 percent of taxable payroll. Over an infinite horizon, the present value of the financing shortfall is approximately $\$ 11.1$ trillion or approximately 3.5 percent of taxable payroll.

The presence of this funding gap has generated a number of proposals to change the structure of the system and to adjust the growth of future benefits, among other considerations. One provision that has been the subject of considerable attention is what is known as "price indexing." The following section explains four different assumptions about price indexing and draws distinctions between different methods of shifting from a wage indexed to a price indexed benefit system. 


\section{Alternative Methods of Price Indexing Social Security}

There are a wide range of reform options available that could help restore Social Security's long-term financing, including changes to both taxes and benefits. ${ }^{12}$ One particular reform proposal that has received substantial attention from policy makers, in part due to its inclusion in the final report of the 2001 President's Commission to Strengthen Social Security, involves switching from a "wage indexed" system (i.e., present law) to a "price indexed" system. The logic of this approach is to shift from a system where benefits are meant to keep pace with the relative standard of living to one that keeps up with the cost of living (Koitz, 1999). Under price indexing, replacement rates would decline, although the real purchasing power of benefits would be maintained.

What exactly constitutes "price indexing" has been the subject of some disagreement. ${ }^{13}$ This debate has arisen in part due to the variety of price indexing proposals that have been recommended over the last thirty years of Social Security debates, and in part due to the multiplicity of ways that the formula or parts of the formula can be adjusted to achieve various policy objectives.

For example, roughly 25 years before the 2001 President's Commission, when the Congress was in the midst of creating the current benefit structure, the Consultant Panel on

\footnotetext{
${ }^{12}$ Nearly every reform option that addresses the fiscal shortfall can be characterized as a change in taxes (including changes to the tax base and/or the tax rate) or as a change in benefits. For example, increasing the Full Retirement Age is analytically equivalent to a reduction in benefits at all ages. One possible exception is that changes in coverage, such as including state and local workers that are not currently covered by Social Security, is not easily classified as a change in benefits or taxes.

${ }^{13}$ A common misconception concerns what part or parts of the formula would be price indexed. See Memorandum from Stephen C. Goss, Deputy Chief Actuary, to Harry C. Ballantyne, Chief Actuary, November 24, 1998. For another example, Diamond and Orszag (2005) suggest that the approach advocated by the 2001 President's Commission is "somewhat misleadingly referred to as "price indexing."
} 
Social Security, chaired by William Hsiao, recommended calculating the growth in benefits on the basis of a form of "price indexing" (Diamond et al 1976). Still different proposals and forms of price indexing have been offered by former Congressman John Kasich, the 2001 President's Commission to Strengthen Social Security, and U.S. Senator Lindsay Graham, each of whom have offered similar or modified version of price indexing. A recent proposal by Robert Pozen combines a form of price indexing for high earners with continued wage indexing for low earners. This latter approach has received considerable attention since President Bush endorsed a similar approach in a press conference on April 28, 2005.

The multiplicity of approaches reflects the fact that prices and wages enter into the current benefit computation in multiple places. For example, along the path from converting lifetime nominal wages into an actual retirement benefit, the average wage index (AWI) is used to index an individual's wages prior to computing the AIME and is also used to adjust the two bend point dollar amounts in the PIA formula. Thus, one form of "price indexing" would involve indexing each worker's earnings to age 60 by prices. A second would change the indexation of the bend point dollar amounts. A third involves the combination of these two. ${ }^{14} \mathrm{~A}$ fourth approach that has emerged in more recent years would reduce the PIA factors, which have remained fixed since 1977, by the ratio of the change in prices to wages. ${ }^{15}$

In this section, we explain how each of these approaches works. A visual illustration of how these alternative approaches affect the calculation of benefits is provided in figure 3 . In later sections, we examine the implication of each alternative approach for benefit levels, replacement rates, and fiscal sustainability.

\footnotetext{
${ }^{14}$ Goss, ibid.

${ }^{15}$ Goss, ibid. Goss, Stephen C., and Alice H. Wade, 2000.
} 


\subsection{Method 1: AIME Indexing}

The current Social Security system indexes a retired worker's past earnings to the average wage level in the year the retired worker turns age 60. Under AIME indexing, earnings would gradually be indexed to the level of prices at age 60 . Indexing by prices expresses each prior year's wage in terms of the quantity of goods and services it could purchase at the time of retirement, while indexing by wages expresses each prior year's wage in terms of what the wage would be if the worker were employed in a similar job at retirement (Thompson, Van de Water, and Ross, 1976).

Because wages tend to grow faster than prices, a shift from wage to price indexing past earnings would likely result in lower AIME amounts for future retirees. To illustrate, recall that a worker earning $\$ 5,572$ in 1968 , under the current law wage indexing formula, would receive credit for earning $\$ 33,252$ in that year. If we instead use price-indexing when calculating an AIME, this $\$ 6,000$ would lead to a credit of only $\$ 28,036$ in earnings. ${ }^{16}$ Since the system currently indexes individual earnings by economy-wide wages, shifting gradually from wageindexing to price-indexing would produce a prolonged but ultimately one-time reduction in scheduled benefits. After approximately 40 years, a retired worker's lifetime earnings would be fully price indexed.

As discussed by Thompson et al, (1976), the choice of an indexing instrument is dependent upon both a philosophical choice of what earnings social security benefits are designed to replace and, at a more pragmatic level, what effect a type of indexing would have on different groups of workers. Philosophically, the price indexing of lifetime earnings would reflect the view that taxable earnings should be measured in terms of what command over goods and services they gave the worker. Wage indexing would reflect the view that earnings should be

\footnotetext{
${ }^{16} \$ 6000$ dollars in 1968 equals $\$ 28,036$ in 2002 adjusted for inflation (CPI).
} 
measured relative to other wage earners. Simply put, price indexing earnings would replace a standard of living in absolute terms, while wage indexing would replace a standard of living in relative terms.

At a more pragmatic level, a shift from wage to price indexing of earnings entering the AIME calculation would put greater weight on earnings that occurred later in a worker's life. Thus, such a shift would decrease the portion of Social Security benefits going to those whose relative earnings decline over time, i.e., those with age-earnings profiles that are flatter than average. For example, individuals who forego higher education to enter the labor force early would receive a smaller share of overall benefits than individuals that pursue higher education and whose earnings rise more steeply over their lifetimes.

\subsection{Method 2: Bend Point Indexing}

The second method would alter the PIA bend points instead of the AIME calculation. Bend Point Indexing would adjust the bend point dollar amounts in the PIA formula annually by the change in prices rather than the change in average wages. For example, assuming the 2005 OASDI Trustees' intermediate assumptions for future wage and price growth, wage-indexing would increase the first bend point amount in the PIA formula from $\$ 627$ in 2005 to $\$ 652$ for 2006, reflecting the increase in average wages. Using Bend Point Indexing, the first bend point

would increase to only $\$ 645$, reflecting changes only in the consumer price index. In contrast to AIME Indexing, Bend Point Indexing would not reach a completed phase-in end period. The bend points would continue to grow at the rate of inflation indefinitely, until or unless Congress acted to alter the formula again. 
Because the bend points are designed to contribute to the progressive structure of the benefit formula, the indexing of the bend points to prices instead of wages would reduce, over a considerable period of time, the progressive design of the PIA formula. Indeed, if the AIME calculation continued to be based on wage indexed earnings, while the bend points were indexed to prices, then in the long-run the system asymptotes toward a linear benefit structure. That is, the benefit would approximate an equal proportion of past earnings for all retirees regardless of their lifetime earnings.

\subsection{Method 3: Bend Point/AIME Indexing}

Bend Point/AIME Indexing would combine the above two methods. Thus, earnings would be indexed to prices instead of wages when calculating the AIME, and then this revised AIME would be fed through a PIA formula that indexed the bend point dollar amounts to prices. As in method 1, the AIME indexing portion of this method would cease affecting benefits after about 40 years, leaving only the bend point indexing. After that phase-in period, the method would be identical to Bend Point Indexing in terms of future growth.

Several advisory commissions in the 1970s considered moving from the current wage indexed benefit formula to one based upon Bend Point/AIME indexing. The 1976 Consultant Panel on Social Security to the Congressional Research Service made this recommendation, calling it "fair and necessary" based upon the projected increase in costs and in real benefit levels inherent with maintaining a wage indexed benefit formula into the future (Diamond, Hickman, Hsiao, and Moorhead, 1976, p. 23). "While the price indexing method implies protection from inflation and a growth in benefits with the real growth of the economy, the wage indexing method calls for a much larger growth in benefits for future retirees at a time when the country 
may not be able to afford it. Use of the price indexing method would permit moderate tax and benefit increases to aid those recipients with greatest need as perceptions of those needs arise" (Diamond, Hickman, Hsiao, and Moorhead, 1977).

Similarly, five of the 13 members of the 1979 Advisory Council on Social Security recommended a future shift from wage indexing to AIME/Bend Point Indexing, in order to "assure successive generations of retirees who have the same real earnings history the same real benefit." The Advisory Council members favoring this shift cited two reasons. First, "future Congresses will be better equipped than today's Congress to determine the appropriate level and composition of benefits for future generations." Congress could still choose to increase benefits versus this price indexed level, and the Council members believed it was likely to do so, but argued that such decisions should be made at the time rather than pre-determined through the benefit formula. Second, "as per capita income rises, the cause for increase the amount of mandatory 'saving' for retirement and disability through Social Security is far weaker than was

the rationale for establishing a basic floor of retirement and disability protection..." (Aaron et al 1979).

While the combining of AIME and Bend Point price indexing would slow to some degree the gradual flattening of replacement rates that would occur under Bend Point Indexing alone, the ultimate effect of combining AIME and Bend Point Indexing would be quite similar (Goss, 1999).

\subsection{Method 4: PIA Factor Indexing}

Under PIA Factor Indexing, the AIME and bend points would continue to be wage indexed as under current law, but the 90 percent, 32 percent and 15 percent factors would be 
reduced by the ratio of the change in prices to the change in wages. In practice, this method would multiply each PIA factor by the ratio of price growth to nominal wage growth in the second year prior to the retiree's first year of eligibility. For example, the 2005 Social Security Trustees Report's intermediate assumptions project that wages will grow by 3.9 percent (represented by 1.039) per year and that prices will grow by 2.8 percent (represented by 1.028 ) per year. The ratio of price to wage growth would thus equal 0.989 . Table 1 shows the change in the PIA factors over time under the PIA Factor method. Under PIA Factor Indexing, each PIA factor would be multiplied by this ratio, reducing the 90 percent factor for 2006 to 89.0 percent, the 32 percent factor to 31.7 percent, and the 15 percent factor to 14.8 percent.

The effect would be to freeze the level of benefits in inflation-adjusted terms, while maintaining roughly the same degree of treatment of different wage levels as the current benefit formula. Indexing the PIA factors would lead to the average initial benefit level being fixed in real terms over time. Interestingly, none of the previous approaches leads to this outcome.

President Bush’s Commission to Strengthen Social Security employed this method in one of its three proposals, saying "The new price-indexing policy slows the growth in future benefits. But, it ensures that future retirees will receive inflation-adjusted benefits that are at least as high as the benefits received by today's retirees." (President's Commission to Strengthen Social Security 2001). A more recent proposal by Robert Pozen would utilize this form of price indexing for individuals at the top end of the earnings distribution, but would continue to wage index the system for approximately the bottom 30 percent of the AIME distribution. Individuals above the $30^{\text {th }}$ percentile, but below the very top, would experience a mix of wage and price indexing. 
The PIA Factor price indexing method, when applied to the entire benefit formula as suggested by the President's Commission, would result in retirement benefits that increase by the actual cost of living for beneficiaries, but not above that rate. Therefore, it would reduce replacement rates over time because benefits would no longer keep up with wage growth in excess of price growth. In the very long run, as wages grow faster than prices, average replacement rates under this approach asymptote toward zero, as do the payroll tax rates required to keep the system in annual fiscal balance. However, it should be noted that, occasionally, inflation rises faster than wages (as in 2001 and 2002). During these years the PIA factors for that year's retirees would actually increase, resulting in an increase in benefits relative to wage indexing.

\section{Effect of Price Indexing on Average Benefit Levels}

To show the effect of the different methods of price indexing on benefits, we project benefit levels and replacement rates for average and constant level wage earners using wage and price data from the Intermediate Assumptions of the 2005 Social Security Trustees Report, assuming that all changes to the benefit formula begin in 2006 . We assume for purposes of these calculations that all beneficiaries would claim benefits at the FRA. Importantly, we did not model these provisions as "proposals," i.e., we did not assume that those nearing retirement would be exempt from any reductions in their defined benefits, as has been stipulated in most of the recent reform proposals. Thus, an important caveat is that our calculations should not be used to evaluate specific reform proposals.

We compare the four price indexing methods to two benefit baselines: benefits as promised under current law; and benefits payable under the Trustees assumptions. The benefits payable baseline assumes that no changes are made in the Social Security program until the Trust 
Fund becomes exhausted, and that the deficit between promised benefits and incoming payroll tax revenues is resolved by reducing benefits across the board for all beneficiaries beginning in 2041. In assessing the difference in benefit levels between the baselines and the methods, the reader should recognize that each baseline and price indexing method would have different implications for program solvency. In particular, it should be noted that the payable benefit baseline assumes that reductions would be applied across the board for all beneficiaries beginning in 2041; if reductions were applied only to newly eligible beneficiaries, the reductions would be larger, and the payable benefit amounts and the replacement rates less than the figures shown here. In comparing benefit levels across approaches, it is also very important to keep in mind that higher benefit levels generally correspond with higher tax burdens on workers. Further analysis of the fiscal effects will be discussed in section 6 below.

AIME indexing, shown in the fourth column of Table 2, would slow the real rate of growth to a low of about 0.4 percent per year, before returning to the growth rate under current law (about 1.1\%). The growth in benefits from year to year under AIME indexing returns to the level of current law because after approximately 40 years, one's earnings would all be indexed to prices and the change from one cohort to the next would essentially be the difference between the each cohort's wages. Bend point dollar amount indexing, shown in the fifth column, would also slow the rate of growth to a low of about 0.4 percent per year above inflation, but for a longer period of time than under AIME indexing, then would gradually increase to 0.5 percent per year by the end of the 75 year valuation period. The sixth column shows benefit amounts under the combination of AIME and Bend Point Indexing. The PIA Factor indexing benefit amounts shown in the last column brings the real growth of benefits to zero for the average worker. 
Of course, the definition of an "average earner" varies by cohort. Specifically, due to assumed real wage growth over time, later cohorts are assumed to have higher real earnings than earlier cohorts. A constant real benefit, when applied to a higher average level of average earnings over time, leads to a decline in average replacement rates. Table 3 illustrates this, showing the retirement benefit expressed as a percentage of pre-retirement earnings. Under the current law benefit formula, replacement rates remain constant for individuals retiring at the Full Retirement Age. Under all other methods replacement rates would fall over time, with the largest decline coming from the bend point factor indexing.

Some of the confusion over the definition of price indexing arises from the fact that the earnings of an "average" worker are different for each cohort. As shown in table 3, a fixed real benefit for an average worker translates into a lower replacement rate for later cohorts due to the growth in average real earnings across successive cohorts. This implies that a fixed real earnings profile would fall ever lower in the earnings distribution as the years go by. Table 4 illustrates the benefits that would be paid to individuals retiring at different times but having the same earnings in inflation-adjusted dollars. These calculations differ from those in Tables 2 and 3, which showed individuals with earnings that were the average in the period in which they were employed, resulting in those retiring in later years having higher real earnings. Table 4 shows a fixed real earnings profile at different periods in time.

Under current law, benefits paid for the same level of constant real earnings rise at roughly 0.4 percent to 0.5 percent per year. This occurs because the bend point dollar amounts are indexed to wage growth, and thus a higher fraction of these earnings become covered by the 90 percent PIA factor in later cohorts. 
AIME indexing would slow real benefit growth for roughly forty years, eventually resulting in negative growth for a few years, after which the growth rate would return to the 0.5 percent annual growth rate contained in current law. Bend Point Indexing would maintain a constant benefit over time for those with constant earnings. This approach, therefore, "price indexes" benefits for a fixed real earnings stream. Note that as we saw in Table 2, however, this implies that a worker with average earnings for their cohort would see continued growth over time. The combination of AIME and Bend Point Indexing would reduce benefits to below the rate of inflation for roughly forty years, after which benefits would remain constant for a given real wage profile.

PIA Factor Indexing, which produces constant real benefits for the average earner, would decrease the benefits for the fixed earnings profile to a rate of about 0.5 percent below the growth in prices for the valuation period. Thus, the benefit is fixed in real terms for a worker at the same point in the earnings distribution, but declines for a given level of real lifetime earnings.

\section{The Effect of Price Indexing on Replacement Rates}

The degree of "progressivity" of the Social Security system is the subject of some controversy in the literature. If one were to assume that all individuals have identical survival probabilities and that an individual's AIME is a good indicator of lifetime economic status, then the Social Security retirement benefit formula would clearly result in a progressive system. This is because the ratio of PIA/AIME is a declining function of AIME. In other words, the Social Security benefit formula is designed to replace a higher fraction of pre-retirement earnings for lower income individuals.

Recent research has clearly shown, however, that having the PIA/AIME ratio decline with AIME is not sufficient to ensure overall progressivity for several reasons. First, it has been 
well-documented that higher income individuals have, on average, lower mortality rates. As a result, they tend to receive their monthly benefit check for more months. Second, individual AIME is not always a good indicator of the lifetime economic resources available to the individual. This is because the AIME calculation excludes a variety of relevant economic factors, such as the labor earnings of one's spouse as well as non-labor income. Determining progressivity is made all the more complex when one considers the spousal and dependent benefits available from Social Security.

For example, consider a college-educated woman with strong earnings potential who is married to a high earning spouse. If, over the course of her career, she voluntarily chooses to have only intermittent attachment to the formal labor market, she would enter retirement with a relatively low AIME. Based on her low AIME, she would receive a high replacement rate, because most, if not all, of her AIME would fall below the first bend point and thus be credited with a 90 percent replacement rate. When evaluated on an individual basis, this may look like a progressive policy because this low-income individual just received a higher replacement rate. But when evaluated on a household basis, for example, the system is effectively providing a high replacement rate to a member of a high earning household.

Despite the complexities of evaluating overall progressivity, the comparisons of PIA/AIME across the AIME distribution is still of some value, if for no other reason than that this is an important input into broader progressivity calculations. As such, while one must view such comparisons with some caution, we proceed with a comparison of replacement rates across different points in the AIME distribution for each of the four indexing methods. Of course, even this simple comparison requires caution, as two of the methods (1 and 3) alter the calculation of the AIME itself. 


\subsection{Indexing past earnings to prices}

Changing the indexing of past earnings to prices instead of wages (used in methods 1 and 3) has two effects on the AIME. First, assuming positive real wage growth, it unambiguously reduces the AIME of all workers. Reducing the AIME for all workers has a direct effect on the extent of redistribution, because it reduces benefits more for lower income individuals than higher income individuals. This arises because of the progressive bend point dollar amounts for a given reduction in AIME, a person with an AIME below the first bend point would receive 90 cents less for every dollar decrease in their AIME while a person with earnings over the second bend point would receive only 15 cents less for every dollar decrease in their AIME.

Second, relative to current law, price indexing earnings in the AIME calculation increases the weight on earnings at older ages and decreases the weight on earnings at younger ages. This means that workers with relatively flat age-earnings profiles will experience a larger percentage decline in their AIME than workers with a more positively sloped profile. Burtless et al (1999) show estimated age-earnings profiles for five education groups, and provide strong evidence that the age-earnings profile is much steeper for individuals with higher levels of education than for lower levels of education. For example, they find that "among men with the least schooling attainment, relative earnings begin to fall as early as age 40" while "men who have completed college do not experience sizable relative earnings declines until their 50s." Because individuals with lower levels of education have lower average earnings and flatter age-earnings profiles, the switch from wage to price indexing of past earnings will result in proportionately larger declines in their AIMEs. 


\subsection{Indexing the Bend Points}

Changing the indexing of the bend point dollar amounts results in non-monotonic percentage reductions in replacement rates across the AIME distribution. Figure 4 provides a graphic depiction of the PIA formula at a future point in time under wage (OLD) versus price (NEW) indexing of the bend points. As illustrated by figure 4, beneficiaries whose AIME falls below point A (the new first bend point under price indexing) would not be affected. This is because all of their AIME would still be multiplied by a PIA factor of 90 percent. All workers above the new first bend point would receive some reduction in benefits relative to wage indexing, because all income that was below the first bend point when wage indexed (point B) but above the price indexed bend point (point A) will have that marginal income replaced at a rate of 32 percent instead of 90 percent. This means there is some additional progressivity built into the system, because the lowest income individuals are spared any benefit reduction.

However, as we move up the AIME distribution, all workers who earn more than the old first bend point (B) and less than the new second bend point (C), experience the same dollar reduction in benefits. However, this means that this fixed benefit reduction (equal to the vertical distance between the two lines) is a larger percentage change for individuals with a lower AIME. Graphically, individuals with AIME just above B will experience a much larger percentage reduction in benefits than individuals with AIME just below point $\mathrm{C}$. A similar phenomenon occurs above point $\mathrm{D}$ - the old second bend point. The net result is a non-uniform benefit change, such that those individuals who have an AIME at or slightly above the existing bend point dollar amounts would experience the largest percentage reduction in benefits.

In the long-run, if average earnings continue to rise faster than prices, an ever larger fraction of the AIME distribution will lie above both bend points, which leads to an ever-larger 
share of earnings being replaced at the 15 percent rate instead of the 90 percent or 32 percent rate. Indeed, in the very long run, the replacement rate of the entire distribution of workers asymptotes to a single 15 percent rate. Thus, while the percentage benefit reductions are very uneven across the distribution of AIME in the short run, the long run effect is to collapse the system to a nearly linear benefit level with a 15 percent replacement rate, meaning that at some point nearly all retirees would receive a roughly equal percent of their earnings back in the form of a Social Security benefit. The progressive design of the current formula, in other words, would be reduced to a nearly linear formula offering an effective flat rate benefit.

\subsection{AIME / Bend Point Indexing}

Method 3 is simply a combination of methods 1 and 2. Price indexing earnings in the AIME formula still has the effect of increasing the relative weight of later earnings, which can be regressive if the age-earnings profile is flatter for lower income individuals. Layered on top of this is a change to the bend point dollar amounts that has the largest percentage effect on those nearest the bend points.

\subsection{Indexing the PIA Factors}

In contrast to the other approaches, PIA Factor price indexing would reduce the PIA by the same percentage at all points in the AIME distribution. Higher earners would continue to receive lower benefits relative to their pre-retirement earnings than would lower earners, thus preserving the basic redistributive feature of the current formula.

Of course, in the very long run, as wage growth continues to outpace inflation, the replacement rates under this approach asymptote to zero, as does the payroll tax rate required to 
sustain the benefit payments. Alternatively, once the level of program expenditures are low enough to be fully financed by the existing 12.4 percent payroll tax rate, benefits could once again be permitted to grow in real terms at a rate determined, in part, by the rate of growth in payroll tax revenue.

\section{Effect of Alternative Approaches on Long-Term System Finances}

The previous two sections focused on how changes to the benefit formula would affect benefit levels and distribution. The other side of the coin, however, is program cost. Because the level of benefits scheduled under current law are higher than can be sustained by existing tax rates, it is essential to also consider the effect of alternative methods of price indexing on total system costs. Not surprisingly, the four alternative methods have very different implications for the long-run financial situation facing Social Security.

For purposes of this paper, we will summarize the fiscal effect of these alternative policies by examining the 75 -year actuarial deficit. This measure has long been used by Social Security actuaries as a summary measure of the long-term status of the system. It is, however, far from a perfect measure, and in many cases can providing a misleading view of the net fiscal effects of certain reform options that make important changes outside of the 75-year window (Gokhale and Smetters 2005).

For example, consider a reform option, such as an expansion in Social Security coverage to newly hired state and local workers, that increases revenue immediately but which increases the long-term liabilities of the system. Even if this expansion in coverage were actuarially fair for every new participant, and thus had no effect on the present value of Social Security's deficits, it could still lead to an improvement in the 75 -year actuarial balance. This occurs because the arbitrary 75-year cap on the calculation effectively counts 75 years worth of 
additional tax revenue but counts only a fraction of the additional benefits that are accrued during this period. ${ }^{17}$ To see this simply, consider a (not yet born) state and local worker who begins work 50 years from now, works for 25 years, and retires 75 years from now. The 75 -year calculation implicitly "takes credit" for the present value of 25 years worth of taxes paid, but completely ignores the present value of the benefits because they lie outside the valuation window.

Another example of the bias induced by a truncated 75-year horizon is when a proposal seeks to pre-fund future benefits, such as through personal accounts. Consider a proposal that redirects some existing payroll tax revenue into personal accounts in exchange for an actuarially fair reduction in future benefits. On an infinite horizon basis such a policy would have zero effect on the present value of the system. However, because such a policy re-times the cash flows so that there are higher cash outlays in the early years, this shows up in a 75-year calculation as a significant increase in the actuarial liabilities of the system.

A common feature of these examples (adding state and local workers, transitioning to accounts) is that the reforms affect both revenues and outlays, and do so in a way such that the timing of the changes is different for each. In recent years, the Social Security Trustees have expanded their analysis to consider infinite horizon measures in addition to the traditional 75year measure. The use of multiple measures is valuable for distinguishing between proposals that simply re-time receipts and outlays, from those that influence the net long-run position of the program.

\footnotetext{
${ }^{17}$ The distinction between cash flow and accrual accounting is quite significant. For example, Jackson (2004) shows that if the Social Security system used accrual accounting instead of cash flow accounting, the Social Security trust funds would have had to report a net loss of several hundred billion dollars in 2002 instead of a $\$ 165$ billion increase in net assets.
} 
In contrast to reforms that re-time expenditures or change both outlays and expenditures according to different timetables, all four of the price indexing measures operate by simply slowing the growth rate of benefits. These approaches do not involve changes in payroll tax receipts that are partially offset by future benefit changes, nor do they involve any attempt to prefund future benefits. Rather, all four approaches leave the path of payroll tax revenue unchanged ${ }^{18}$ and gradually reduce the growth in program expenditures. Thus, the use of a 75year actuarial measure is somewhat less problematic in this context, although it understates the long-term savings by ignoring years 76 and beyond. However, it is relatively simple to offer a qualitative assessment of the differential longer-run effects of these methods on program finances.

Figure 5 provides a side-by-side comparison of each method's effect on Social Security's 75-year OASDI actuarial balance. The recently released 2005 OASDI Trustees' Report projected a 75 -year deficit of 1.92 percent of taxable payroll. However, because the last actuarial estimates (Goss and Wade, 2000) available for the price indexing options are those based on the 1999 Trustees' Report, which projected a long range deficit of 2.07 percent of taxable payroll, our analysis of the four options' solvency effects is determined by using the 1999 Trustees' Report estimates. ${ }^{19}$ Based on these 1999 assumptions, only the PIA Factor method (Method 4) would make the Social Security program solvent over the next 75 years.

AIME Indexing (Method 1) would have the smallest effect on program solvency of the four proposals, eliminating approximately 0.70 percentage points of the projected payroll deficit

\footnotetext{
${ }^{18}$ There is a small differential effect of these policies on program revenue due to the taxation of benefits, but this effect is quite modest relative to the fiscal impact on the expenditure side.

${ }^{19}$ All four price indexing methods would likely make a greater contribution to system solvency under the 2005 assumptions of the Social Security Trustees. Any price indexing method will improve solvency when the differential between wage and price growth increases. Under 1999 assumptions the long-term real wage differential was projected at 0.9 percent annually, while under 2005 assumptions it is projected at 1.1 percent.
} 
in the Social Security program. Bend Point Indexing (Method 2) would eliminate approximately 1.35 percentage points. Thus, neither of these approaches is sufficient to restore fiscal balance to Social Security. As a result, either additional reductions in future benefits or increases in tax revenues would be required to restore long-term fiscal sustainability. Employing both of these indexing methods together (Method 3) would eliminate 1.95 percentage points of the payroll tax deficit.

PIA Factor Indexing (Method 4) would eliminate 2.36 percentage points of the shortfall, and would achieve solvency in perpetuity. Indeed, this approach reduces long-run costs by more than enough to ensure sustainable solvency and results in large and growing surpluses in the distant future. Thus, either tax rates could be reduced or benefits could be increased above what is assumed in this calculation. Of the four methods, therefore, PIA Factor Indexing is the only one that has been projected to permanently eliminate the entire financing shortfall facing Social Security.

\section{Further Policy Discussion}

This paper has focused on four alternative methods of price indexing Social Security benefits. Of the four methods considered, PIA Factor Indexing generates the largest cost savings for the Social Security system. It does so by reducing the rate of growth of benefits by a roughly equal percentage across the entire earnings distribution, thus maintaining approximately the same relative redistribution as current law.

Of course, the flip-side of the substantial reduction in long-term program expenditures is that PIA Factor Indexing also generates the largest reductions in future replacement rates. Indeed, even though the real level of average benefits remains fixed, the average replacement 
rate asymptotes toward zero in the very long-run. As a result, if a large subset of future beneficiaries continued to rely on Social Security for most or all of their retirement income, this group would likely experience large declines in their relative standard of living at retirement. Of course, as the replacement rates decline over the long-run, so do the payroll tax rates required to keep the system in annual fiscal balance. In order to avoid this, initial benefit levels could be permitted to start growing once again after the system is back into annual fiscal balance.

In general, as we have already noted, it is important to consider more than just the cost savings from any change to the benefit formula. For example, one's choice of approaches also ought to reflect such considerations as benefit adequacy and desired redistribution both within and across cohorts. Each approach to price indexing, for example, has different effects and is therefore consistent with different policy purposes.

Another important factor to consider is the effect of reform on the stability of system finances in the face of unexpected future changes in economic or demographic assumptions. For example, the "de-linking" of benefit growth from wage growth, while allowing tax revenues to continue to rise with wages, is the mechanism by which PIA Factor Indexing results in substantial long-run cost savings. However, this approach also increases the degree of sensitivity of Social Security's finances to unexpected changes in these economic parameters. Unexpected increases (decreases) in real wage growth will have a much larger positive (negative) effect on long-run fiscal balance under price indexing than under wage indexing of benefits. In this sense, holding the expected size of any fiscal imbalance fixed, a system in which benefits and taxes are effectively indexed in the same way leads to a more stable outcome than a system in which revenues rise with wage growth while benefits do not. In short, a move to price indexed benefits will result in a system that is less resilient to unexpected earnings changes. It is worth noting 
that the same level of expected cost savings could be achieved without decreasing stability by simply choosing a pre-determined path by which the PIA factors are reduced that is not conditioned on ex post realizations of wage and price growth.

There are at least three other important factors that ought to be considered in a complete analysis of any reform proposal, including those that utilize price indexing. While an analysis of these factors is well beyond the scope of this paper, we highlight these issues here. The first is that any method to adjust future benefits may also affect the degree of political risk facing the program in the future. For example, the closer a policy comes to placing the program on a permanently sustainable fiscal path, the less likely it is that future changes will be required as a result of funding concerns. However, if a policy leads in the long-run to concerns about benefit adequacy or redistribution, political risk could increase.

Second, altering the Social Security benefit formula may influence labor supply decisions. For example, the clearer the perceived link between marginal benefits accrued from another marginal dollar of tax paid, the lower the efficiency costs of taxation. ${ }^{20}$ As another example, if a reform alters the relative weight on earnings that occur earlier or later in life, this could influence the desirability of labor force participation near retirement.

Third, changes to the benefit formula, by altering the path of program expenditures over the long-run, can affect national saving, particularly in comparison to alternative approaches to bringing the system back into actuarial balance. As indicated by recent $\mathrm{CBO}$ analyses, this in turn can affect the level of GDP growth. ${ }^{21}$

\footnotetext{
${ }^{20}$ For a general discussion of how the benefit-tax linkage affects efficiency costs of taxation, see Summers 1989.

${ }^{21}$ The CBO estimated that implementation of President's Commission model 2, which includes PIA factor indexing as well as personal accounts, would increase GDP by 3-4 percent by the year 2080 relative to a Trust Fund financed baseline.
} 


\section{Conclusion}

Without changes the Social Security program is expected to be able to pay only 74 percent of scheduled benefits to beneficiaries by 2041. Changing the way retirement benefits are calculated through price-indexing has been proposed as a way of partially correcting this longterm shortfall. This paper describes the alternative methods that could be used to price index initial Social Security benefits for future retirees, analyzes the changes in benefits and replacement rates for future retirees that would result from each approach, and provide estimates of their relative impact on program solvency. We also discuss some of the policy trade-offs that would be inherent in the choice of a price indexing tool.

Of the four methods we examine, PIA Factor Indexing would do the most to slow the growth of initial benefits for future retirees, would change benefits for future retirees at approximately the same rate for all levels of wage earners, and would keep the system growing at the level of price changes for the foreseeable future. However, PIA Factor Indexing would over time, greatly reduce the replacement rate available through Social Security, and would potentially increase the sensitivity of system finances to unexpected changes in relevant economic parameters. 


\section{References}

Aaron, Henry, Gardner Ackely, Mary Falvey, John Porter, and J. W. Van Gorkom. 1979. Social Security Financing and Benefits, Report of the 1979 Advisory Council (Washington: Government Printing Office, 1979).

Burtless, Gary, Barry Bosworth, Eric Toder, Cori Uccello, John O’Hare, Melissa Favreault, Carline Ratcliffe and Karen Smith. 1999. "Final Report: Modeling Income in the Near Term Projections of Retirement Income Through 2020 from the 1931-60 Birth Cohorts." Urban Institute project report. September, 1999.

Congressional Budget Office. 2004a. "Long-Term Analysis of Plan 2 of the President's Commission to Strengthen Social Security.”

Congressional Budget Office. 2004b. "Long-Term Analysis of the Diamond-Orszag Social Security Plan."

Coronado, Julia Lynn, Don Fullerton, and Thomas Glass. 2000. "Long Run Effects of Social Security Reform Proposals on Lifetime Progressivity", February 2000, National Bureau of Economic Research, Working Paper 7568.

Diamond, Peter, James Hickman, William Hsiao, and Ernest Moorhead. 1976. "Report of the Consultant Panel on Social Security to the Congressional Research Service," August 1976.

Diamond, Peter, James Hickman, William Hsiao, and Ernest Moorhead. 1977. Letter to the New York Times, May 29, 1977.

Diamond, Peter and Peter Orszag. 2005. "Price Indexing Initial Social Security Benefits." Tax Notes, January 24, 2005, pp. 471-473.

Gokhale, Jagadeesh and Kent Smetters. 2005. "Measuring Social Security's Financial Problems.” NBER Working Paper No. 11060.

Goss, Stephen C and Alice Wade. 2000. "Estimated Long-Range OASDI Financial Effect of Provisions to Change the Calculation of OASDI Benefits - Information", memorandum to Harry C. Ballantyne, Chief Actuary of SSA, from Stephen C. Goss, Deputy Chief Actuary, and Alice H. Wade, Actuary of SSA.

Gustman, Alan L., and Thomas L. Steinmeier. 2001. "How Effective is Redistribution under the Social Security Benefit Formula?” Journal of Public Economics, Vol 82, No.1, October 2001, pp. 1-28.

Jackson, Howell. 2004. "Accounting for Social Security and Its Reform.” Harvard Journal on Legislation. Vol. 41, No. 1. Winter. pp. 59-159.

Koitz, David S. 1999. "Social Security Reform: Assessing Changes to Future Retirement Benefits", December 14, 1999. Congressional Research Service Code RL30380 
Liebman, Jeffrey B. 2002. "Redistribution in the Current U.S. Social Security System." In Martin Feldstein and Jeffrey Liebman, eds., The Distributional Aspects of Social Security and Social Security Reform. University of Chicago Press. pp. 11-41.

Myers, Robert J. 1993. Social Security. Fourth Edition. Pension Research Council. University of Pennsylvania Press.

Steuerle, C. Eugene, Adam Carasso, and Lee Cohen. 2004. "How Progressive Social Security and Why?", May 2004, Urban Institute, Straight Talk on Social Security and Retirement Policy, no. 37.

Strengthening Social Security and Creating Personal Wealth for All Americans. Report of the President's Commission, December 2001.

Summers, Lawrence H. 1989. "Some Simple Economics of Mandated Benefits." American Economic Review, v. 79 (2): 177-83.

Thompson, Lawrence H., Paul Van de Water, and Jane L. Ross. 1976. "Wage Averaging Rules and the Distribution of Social Security Benefits", A Technical Analysis Paper prepared by the Office of Income Security of the Office of the Assistant Secretary for Planning and Evaluation of the Department of Health, Education and Welfare. 


\section{Table 1: Projected PIA Factor Reductions Indexed with a Ratio of Prices and Wages (in percentage points)}

\begin{tabular}{|c|c|c|c|}
\hline YEAR & $\mathbf{1}^{\text {ST }}$ PIA FACTOR & $\mathbf{2}^{\text {ND }}$ PIA FACTOR & $\mathbf{3}^{\text {RD }}$ PIA FACTOR \\
\hline 2005 & 90.0 & 32.0 & 15.0 \\
\hline 2006 & 89.0 & 31.7 & 14.8 \\
\hline 2015 & 80.9 & 28.8 & 13.5 \\
\hline 2025 & 72.7 & 25.9 & 12.1 \\
\hline 2050 & 55.7 & 19.8 & 9.3 \\
\hline 2075 & 42.7 & 15.2 & 7.1 \\
\hline
\end{tabular}

Source: Office of Retirement Policy tabulations of current PIA factors and 2004 Board of Trustee long range intermediate estimates of average wage and CPI value 2004-2075.

\begin{tabular}{|c|c|c|c|c|c|c|}
\hline YEAR & $\begin{array}{c}\text { Scheduled } \\
\text { Benefits }\end{array}$ & $\begin{array}{c}\text { Payable } \\
\text { Benefits* }\end{array}$ & $\begin{array}{c}\text { Method 1: } \\
\text { AIME } \\
\text { Indexing }\end{array}$ & $\begin{array}{l}\text { Method 2: } \\
\text { Bend Point } \\
\text { Indexing }\end{array}$ & $\begin{array}{l}\text { Method 3: } \\
\text { AIME- } \\
\text { Bend Point } \\
\text { Indexing }\end{array}$ & $\begin{array}{l}\text { Method 4: } \\
\text { PIA Factor } \\
\text { Indexing }\end{array}$ \\
\hline 2006 & 1286 & 1286 & 1286 & 1282 & 1282 & 1272 \\
\hline 2015 & 1415 & 1415 & 1410 & 1374 & 1370 & 1272 \\
\hline 2025 & 1574 & 1574 & 1535 & 1488 & 1449 & 1272 \\
\hline 2050 & 2054 & 1493 & 1818 & 1694 & 1583 & 1272 \\
\hline 2075 & 2680 & 1769 & 2372 & 1903 & 1759 & 1272 \\
\hline
\end{tabular}

Source: Office of Retirement Policy tabulations based on the 2005 intermediate long range estimates by the Social Security Board of Trustees.

*Assumes that reductions would be applied across the board for all beneficiaries beginning in 2041. If reductions were applied only to newly eligible beneficiaries, the reductions would be larger, and the payable benefit amounts less than the figures shown here for illustrative purposes. 


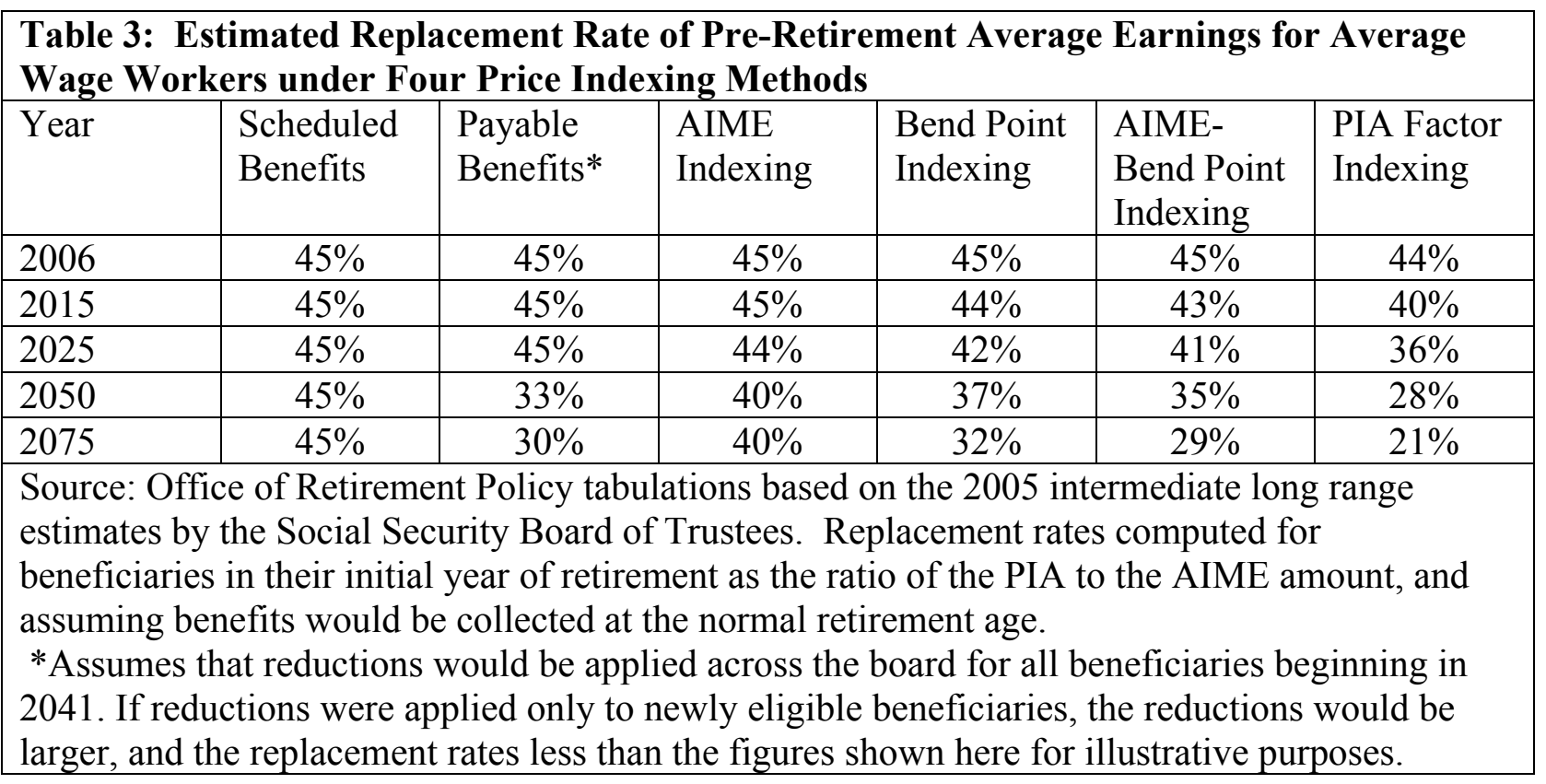

\begin{tabular}{|c|c|c|c|c|c|c|}
\hline Year & $\begin{array}{l}\text { Scheduled } \\
\text { Benefits }\end{array}$ & $\begin{array}{l}\text { Payable } \\
\text { Benefits* }\end{array}$ & $\begin{array}{l}\text { AIME } \\
\text { Indexing }\end{array}$ & $\begin{array}{l}\text { Bend Point } \\
\text { Indexing }\end{array}$ & $\begin{array}{l}\text { AIME- } \\
\text { Bend Point } \\
\text { Indexing }\end{array}$ & $\begin{array}{l}\text { PIA Factor } \\
\text { Indexing }\end{array}$ \\
\hline 2006 & 1138 & 1138 & 1138 & 1134 & 1134 & 1126 \\
\hline 2015 & 1175 & 1175 & 1166 & 1134 & 1125 & 1056 \\
\hline 2025 & 1221 & 1221 & 1180 & 1134 & 1093 & 987 \\
\hline 2050 & 1358 & 987 & 1200 & 1134 & 976 & 841 \\
\hline 2075 & 1537 & 1014 & 1379 & 1134 & 976 & 729 \\
\hline \multicolumn{7}{|c|}{$\begin{array}{l}\text { Source: Office of Retirement Policy tabulations based on the } 2005 \text { intermediate long range } \\
\text { estimates by the Social Security Board of Trustees. } \\
\text { *Assumes that reductions would be applied across the board for all beneficiaries beginning in } \\
\text { 2041. If reductions were applied only to newly eligible beneficiaries, the reductions would be } \\
\text { larger, and the payable benefit amounts less than the figures shown here for illustrative purpose }\end{array}$} \\
\hline
\end{tabular}


Figure 1: AIME/PIA Formula

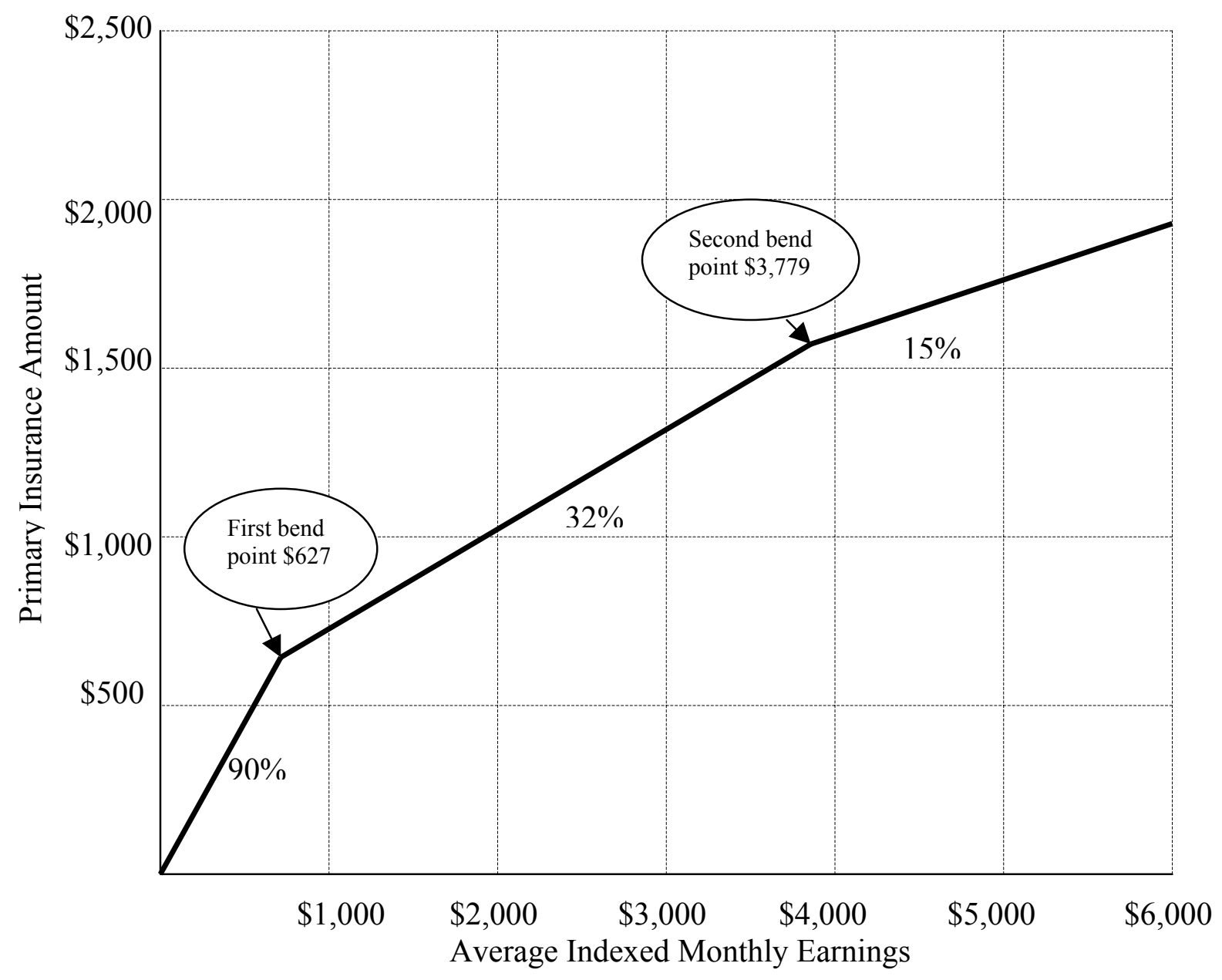


Figure 2: Cost and Income Rates Under Current Law

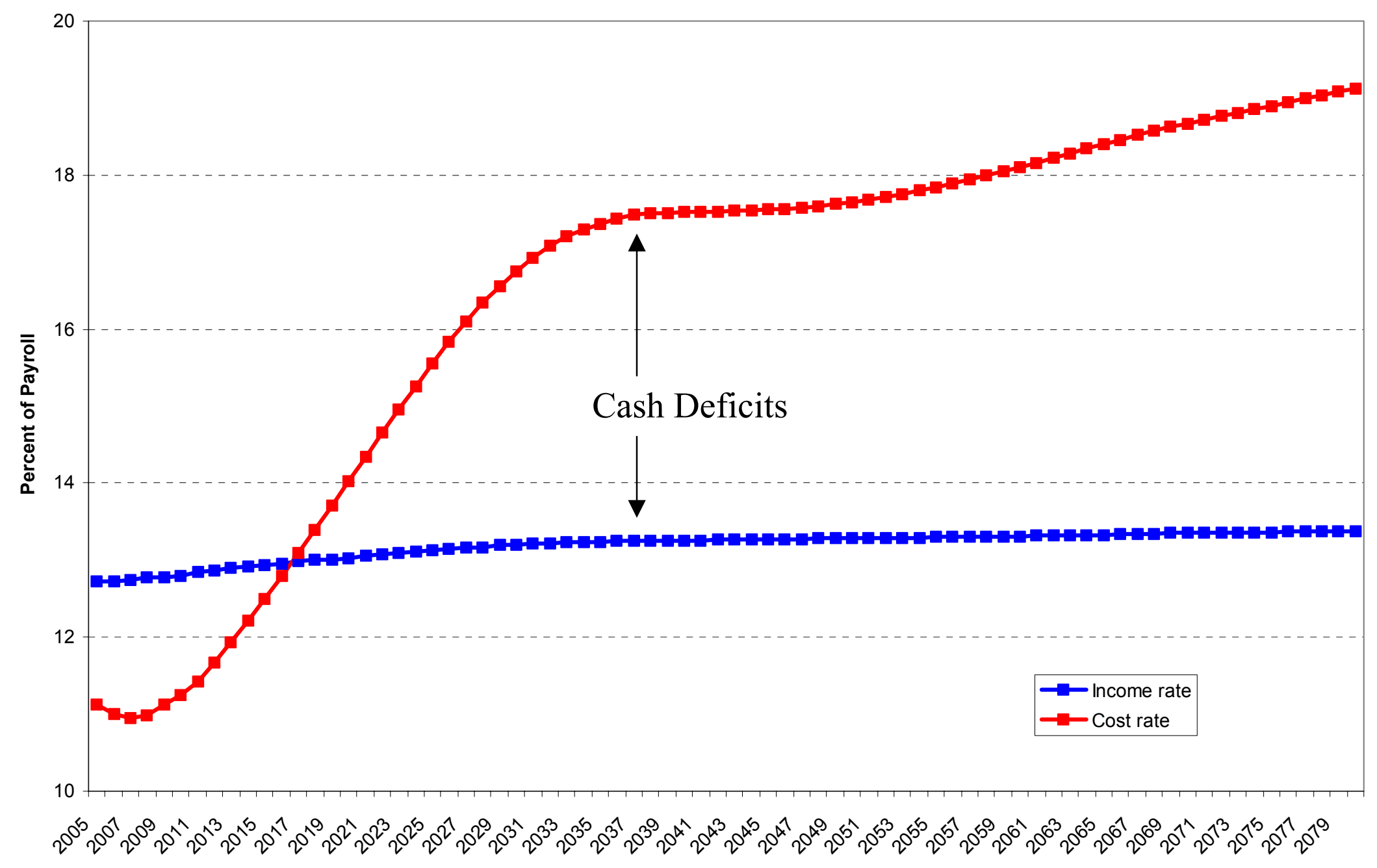


Figure 3:

How Different Forms of Price Indexing Would Alter the Benefit Calculation

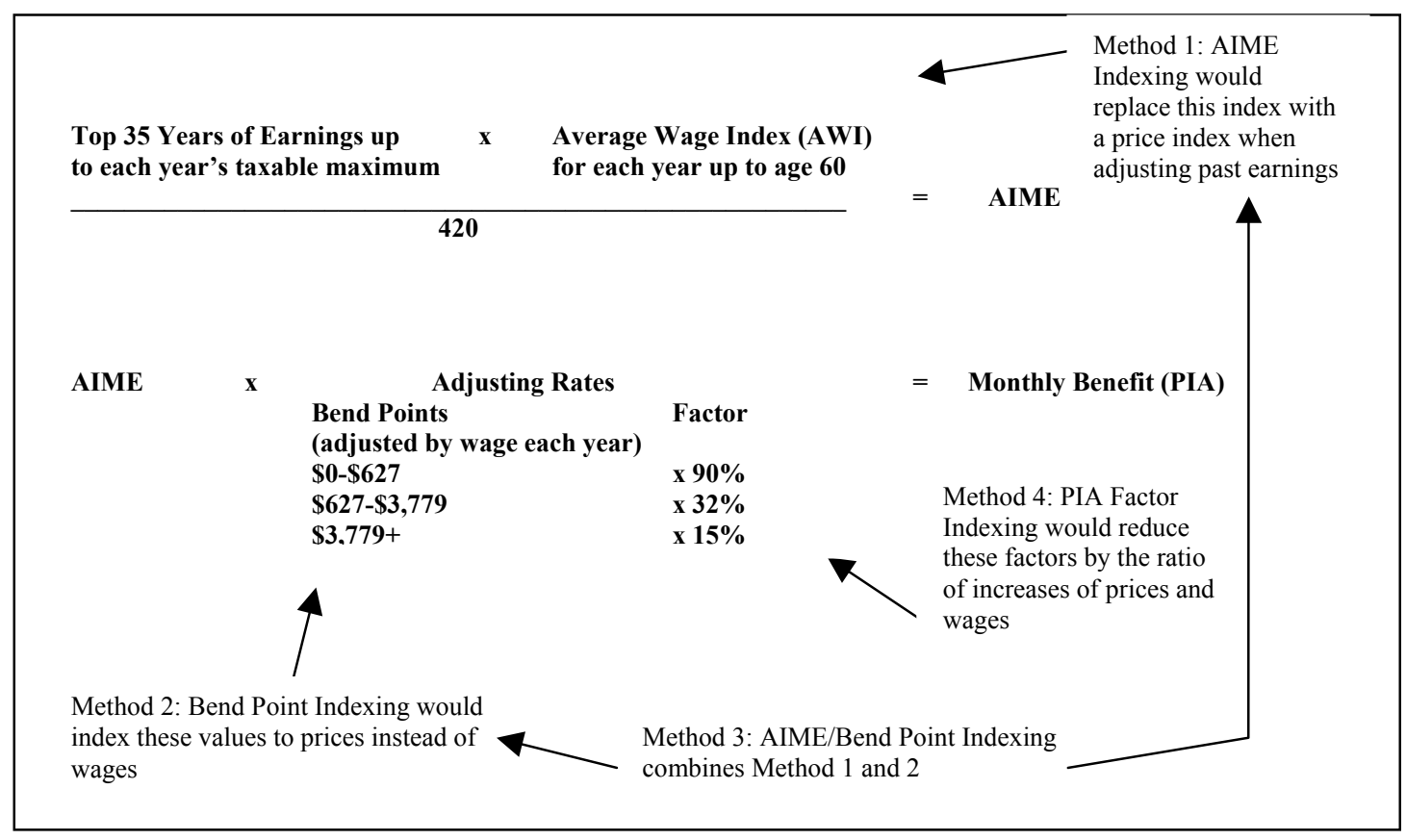




\section{Figure 4: Bend Point Indexing}

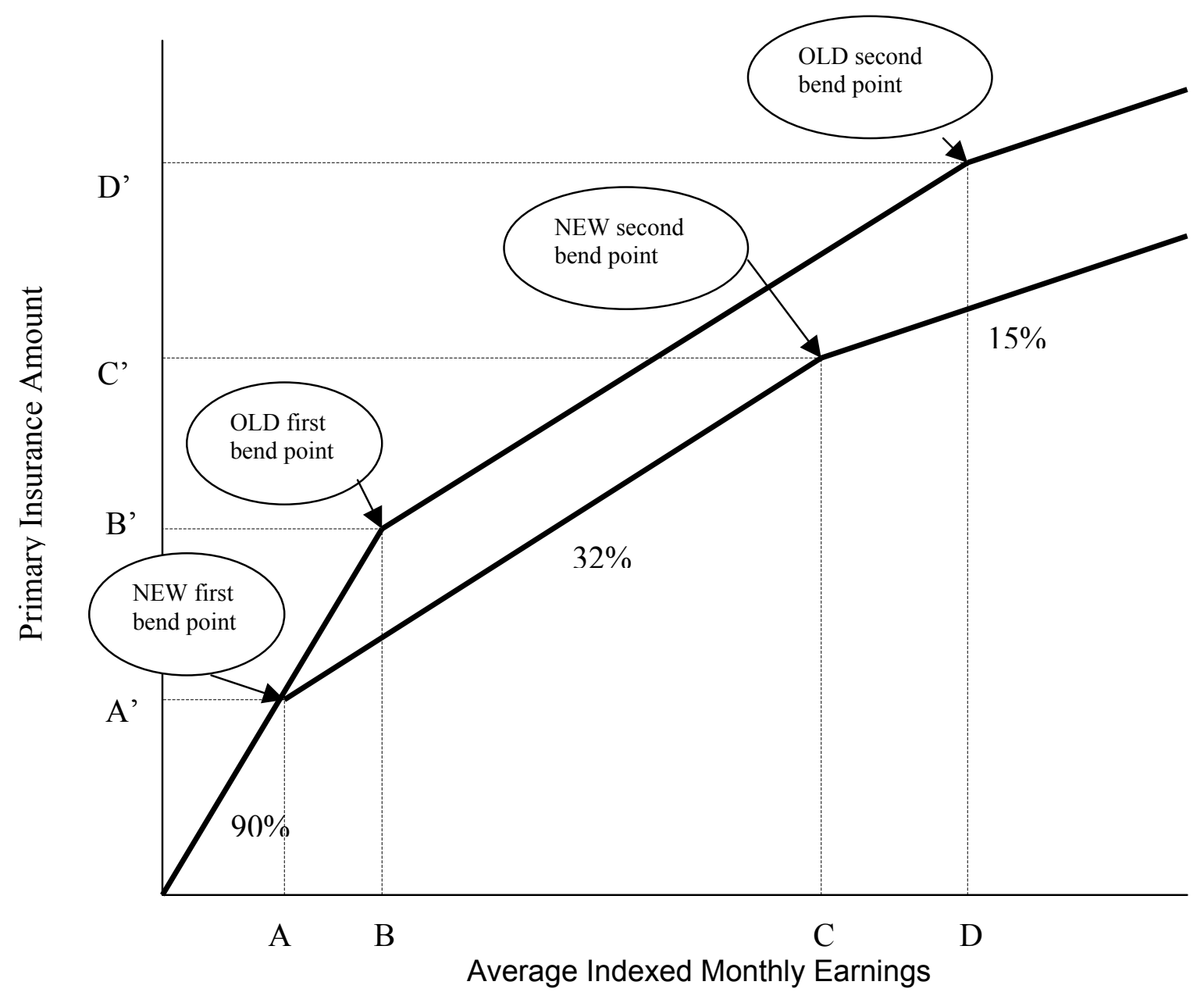




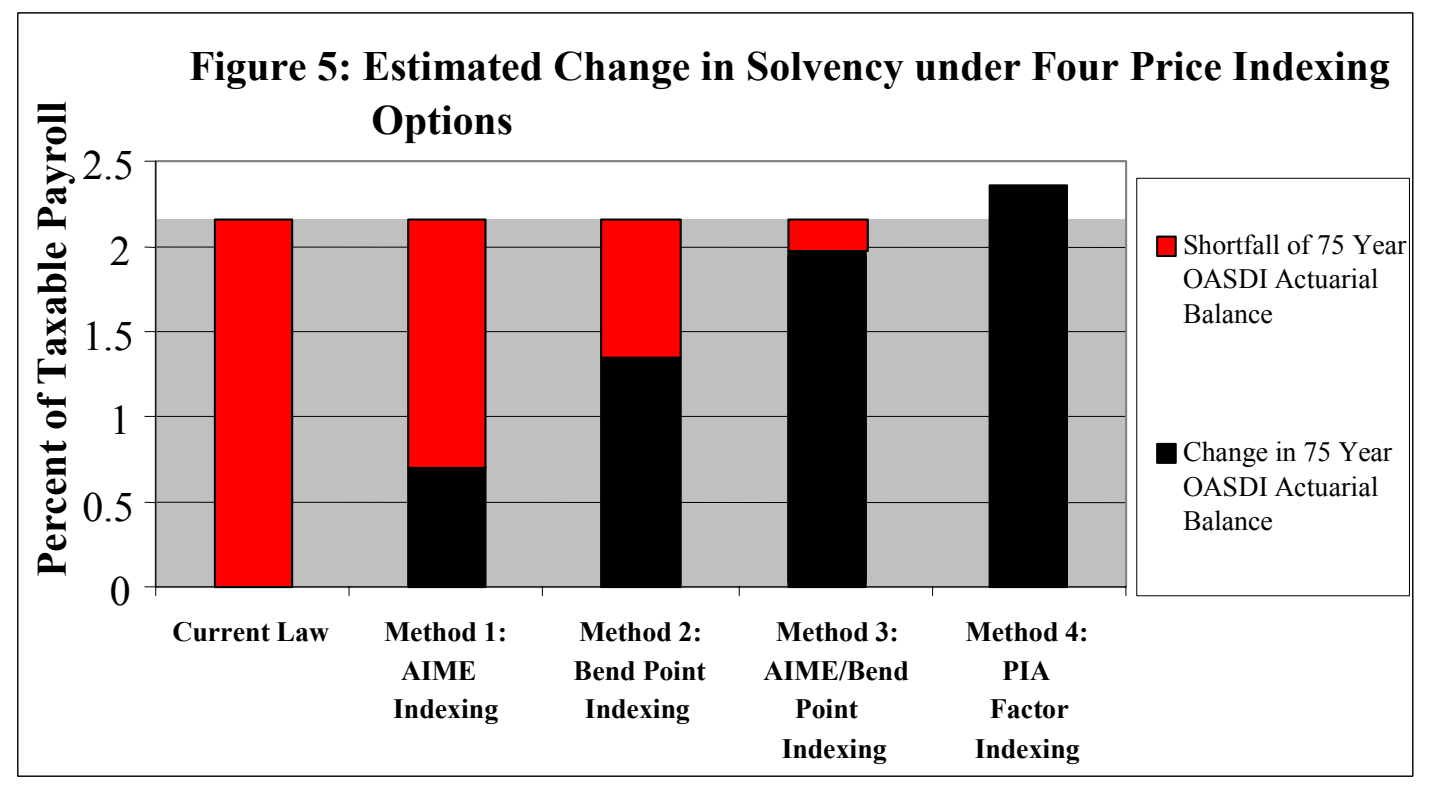

Notes: Calculations based on assumptions in 1999 Trustees' Report, when current law actuarial deficit was equal to 2.07 percent of payroll under Intermediate Assumptions. 